\title{
From plant metabolites to emergence of privileged C-glycosyl scaffolds comprising useful synthetic glycoconjugates
}

\author{
Grzegorz Grynkiewicz* \\ Pharmaceutical Research Institute, Warsaw, Poland
}

In a recently published book on natural products [1] phytochemistry is described as a borderline discipline between plant biochemistry and organic chemistry, which also deals with a variety of subjects, such as biological properties of plant metabolites [(PM); also: secondary metabolites (SM), natural products (NP) or phytoconstituents (PC)] in their host organisms, but also in human beings and other organisms. It might be appropriate to remind that NP data banks list around two hundred thousand compounds, isolated from natural sources, which are of great interest to both fields of science: medicine and nutrition, which constitute fundamental basis for healthcare and sustenance of quality of human life [2-4]. Although this number constitute almost unimaginably small fraction of the chemical space, which accommodates all possible structures (estimates of its size range from $10^{60}$ to $10^{200}$ compounds, while current data bases list ca. $10^{7}$ of known chemical entities), it is generally agreed that a large proportion of currently used therapeutic drugs originate from that small but very diversified collection of NPs. All attempts to explore the chemical space with available chemo-informatic tools suggest that SM clusters contain compounds featuring some structural characteristics distinct from typical synthetic compounds (conveniently summarized as druglike properties) [5-7]. Moreover, we have many reasons to believe that potential of NP for application in human healthcare, well documented in records from ethnopharmacology to the modern medicine, is far from being exhausted. While isolation and collection of individual biologically active NP compounds started at the beginning of XIX century in numerous pharmacists' laboratories, later intervention of chemical structure elucidation methods was necessary to formulate initial pharmacological hypotheses, followed by development of medicinal chemistry, which provided tools to study structure - activity relationships. Plant-derived natural products feature great structural versatility, despite of relatively few biogenetic precursors, drawn from primary metabolic pool. They are traditionally classified as: alkaloids, phenolic acids, sugars, steroids, terpenes, flavonoids, along with a variety of less numerous categories. Remarkably, biogenetic origin notwithstanding, majority of NP become derivatized with monosaccharides or oligosaccharides by the action of ubiquitous glycosyltransferases $[8,9]$. Although all NP compounds are by definition biocompatible, enzymatic glycoconjugation renders them even more bioavailable and susceptible to a bigger number of interactions with macromolecular targets (including non-bonding associations and aglomerations), which include molecular recognition steps. These gains in functional flexibility are achieved by a change in physicochemical properties, like increased solubility in an aqueous environment, and even more so by attaining affinity to a carbohydrate recognizing systems, which are quite common in a cell, tissue and organ biology. Monosaccharides as the building blocks of oligomers, are incomparably richer in structural information than nucleotides or amino acids, which code biological language letters in form of linear sequences. Thus, considering a number of naturally occurring sugar monomers, their ring size, possible substitution patterns and anomeric configurations, even at the level of a trisaccharide, the theoretically possible number of permutations is counted in millions. This situation led to emergence of the glycobiology discipline, which in turn formulated the sugar code hypothesis, now generally accepted as a tool in the bioinformatics field [10]. Since practically all categories of NP contain a fair proportion of glycosidic constituents, they attract attention of life science specialists, as common constituents of regular as well as supplemented diet and also many medication regimens, which are based on herbal drugs. In order to be more specific in the following reasoning, we shell focus our attention on flavonoids (which are often considered a specific but representative class - phenylpropanoids of much larger biologically active group of SM, usually described as plant phenolics) and their glycosides, because they are present in majority of higher plants and therefore, through consumption of fruits and vegetables are a part of regular nutrition in the global scale. At the same time, considerable number of individual flavonoids undergo numerous pharmacological studies, preclinical as well as clinical, as part of drug development projects and programs. Indeed, it has been proven repeatedly that both: flavonoid aglycons as well as their glycosides [11-13] can exert remarkably selective biological actions, either in model experiments or even in the clinical studies, which are of considerable interest for therapeutic practices. In particular, selected flavonoids were shown to act as antioxidants, anticancer, antidiabetic, anti-inflammatory, antiobesity and antipathogenic agents and most of these activities detailed mechanistic studies exist [9,12,14-16]. A dispute concerning the question which form - aglycone or glycoside is preferable as a prospective active principle for application in human medicine remains largely unresolved, although its proven that glycosides are generally not transportable through biological membranes by passive diffusion [16]. Thus, despite wide interest in modern glycobiology as the basis for the glycoconjugate - type novel drug development, relatively few new chemical entities made it through recent registrations, in comparison

${ }^{*}$ Correspondence to: Grzegorz Grynkiewicz, Pharmaceutical Research Institute, 8 Rydygiera Str., 01-703 Warszawa, Poland, Tel: 48224563885; E-mail: g.grynkiewicz@ifarm.eu

Received: July 22, 2018; Accepted: August 10, 2018; Published: August 13, 2018 
to the traditionally established glycosidic therapeutics from such categories as: cardiac glycosides and few groups of antibiotics (e.g. macrolides, polyenes, glycopeptides, anthracyclines) [2-5]. One of the reasons why glycosides of natural origin are good drug leads at the stage of preclinical pharmacology but perform rather poorly at the realm of systemic biology, is their inherent limited metabolic stability in the presence of the sugar processing enzymes [10,15,16]. Thus, plant phenolics and particularly flavonoid glycosides, which undoubtedly play very significant role as dietary constituents in prevention of numerous human pathologies, have as a rule an unfavorable ADMET parameters to be considered for drug development "as such" $[6,7,9]$.
There are many ways to modify NP structures in order to improve their drug-like properties and organic synthesis excel in delivering suitable tools to achieve such goals. In nature, structural analogs of common $\mathrm{O}$-glycosides exist, in which anomeric $\mathrm{C}-\mathrm{O}$ bond is replaced by $\mathrm{C}-\mathrm{C}$ linkage and this formally simple structural alteration results in radical increase of a compound stability toward both: chemical and enzymatic degradation. Natural flavonoid C-glycosides are relatively small group of SM, which are of increasing interest for biochemistry and medicinal chemistry (Figure 1) [17-19]. Although chemical syntheses of C-glycosyl compounds started already in the middle of the XX century, it did not cross the border of fairly minor academic<smiles>CC(=O)Cc1cc(=O)c2c(C)cc(O)c([C@@H]3O[C@H](CO)[C@@H](O)[C@H](O)[C@H]3O)c2o1</smiles><smiles>O=C1c2c(O)cccc2C([C@H]2O[C@H](CO)[C@@H](O)[C@H](O)[C@H]2O)c2cc(CO)cc(O)c21</smiles><smiles>O=C(CCc1ccc(O)c(O)c1)c1c(O)cc(O)c([C@@H]2O[C@H](CO)[C@@H](O)[C@H](O)[C@H]2O)c1O</smiles><smiles>COc1c(O)cc(C(=O)O[Ga])c([C@H]2O[C@@H](O)[C@H](O)[C@@H](CO)O2)c1O</smiles><smiles>O=c1cc(-c2ccc(O)c(O)c2)oc2cc(O)c([C@@H]3O[C@H](CO)[C@@H](O)[C@H](O)[C@H]3O)c(O)c12</smiles><smiles>O=C1C=C([C@H]2O[C@H](CO)[C@@H](O)[C@H]2O)C(=O)N1</smiles>

Showdomycin<smiles>Cc1c(C(=O)O)c(O)cc2c1C(=O)c1c(O)c([C@H]3O[C@H](CO)[C@@H](O)[C@H](O)[C@H]3O)c(O)c(O)c1C2=O</smiles><smiles>COc1c([C@H]2O[C@H](CO)[C@@H](O)[C@H](O)[C@H]2O)c(O)cc2oc3cc(O)c(O)cc3c(=O)c12</smiles><smiles>O=c1[nH]cc([C@H]2O[C@H](CO)[C@@H](O)[C@H]2O)c(=O)[nH]1</smiles>

Pseudouridin<smiles>CCCCCCCCCCCC(=O)c1c(O)cc(O)c([C@@H]2O[C@H](CO)[C@@H](O)[C@H](O)[C@H]2O)c1O</smiles><smiles>O=c1cc(-c2ccc(O)cc2)oc2c([C@@H]3O[C@H](CO)[C@@H](O)[C@H](O)[C@H]3O)c(O)cc(O)c12</smiles><smiles>O=c1c(-c2ccc(O)cc2)coc2c(C3O[C@H](CO)[C@@H](O)[C@H](O)[C@H]3O)c(O)ccc12</smiles><smiles>O=c1cc(-c2ccc(O)c(O)c2)oc2c([C@@H]3O[C@H](CO)[C@@H](O)[C@H](O)[C@H]3O)c(O)cc(O)c12</smiles><smiles>COc1ccc2c(=O)cc(-c3ccc(O)cc3)oc2c1C1C[C@H](O)[C@@H](O)[C@H](C)O1</smiles><smiles>O=c1cc(-c2ccc(O)cc2)oc2cc(O)c([C@@H]3O[C@H](CO)[C@@H](O)[C@H](O)[C@H]3O)c(O)c12</smiles>

Figure 1. Some naturally occurring C-glycosides 
activity until very recently, when new methods of the chemical C C coupling, catalyzed by transition metal complexes, were installed and perfected [20-22]. That development made possible syntheses of C-glycosides not only for proof of structure of newly isolated compounds but as an intentional switch from O-glycosides of natural origin to the synthetic $\mathrm{C}$-analogs with radically increased stability. Contemporary pharmaceutical development can serve as an example of such activity, which met with a spectacular therapeutic success, with all positive consequences on the global markets. Phlorizin, a dihydrochalcone glycoside, was one of the first glycosides isolated from natural source in the state of high chemical purity (1836). Toward the end of XIX century it was identified as an agent producing glycosuria in experimental animals and it soon became a probe for studying an<smiles>O=C(CCc1ccc(O)cc1)c1c(O)cc(O)cc1O[C@@H]1O[C@H](CO)[C@@H](O)[C@H](O)[C@H]1O</smiles><smiles>O=C(CCc1ccc2c(c1)CCO2)c1c(O)cc(O)cc1O[C@@H]1O[C@H](CO)[C@@H](O)[C@H](O)[C@H]1O</smiles>

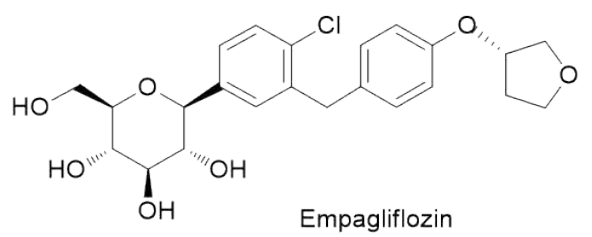<smiles>OC[C@H]1O[C@@H](c2ccc(F)c(Cc3cc4ccccc4s3)c2)[C@H](O)[C@@H](O)[C@@H]1O</smiles><smiles>CCc1ccc(Cc2ccc3c(c2)[C@H]2O[C@H](CO)[C@@H](O)[C@H](O)[C@H]2OC3)cc1</smiles>

urinary tract physiology, with focus on glucose transport in nephrites $[23,24]$. As an established inhibitor of the newly recognized glucose transporting proteins (SGLT) phlorizin became a lead compound for an anti-diabetic drug development, but without much success because of its metabolic instability. Situation changed radically, when the drug development switched to C-glycosyl analogs of phlorizin. In a relatively short time, entire new generation of the oral anti-diabetics has emerged based on the newly designed, metabolically stable glycoconjugates, mimicking the natural origin SGLT prototype inhibitor - phlorizin. These new compounds, under their registered drug names (the group is known under generic collective name of gliflozins), are presented in Figure 2 [25-28]. In retrospective, study of phlorizin underwent two brisk and illuminating phases of research: the renal physiology study<smiles>CCOC(=O)OC[C@H]1O[C@@H](Oc2ccccc2Cc2ccc(OC)cc2)[C@H](O)[C@@H](O)[C@H]1O</smiles><smiles>CCOc1ccc(Cc2cc([C@H]3O[C@H](CO)[C@@H](O)[C@H](O)[C@H]3O)ccc2Cl)cc1</smiles><smiles>Cc1ccc([C@@H]2O[C@H](CO)[C@@H](O)[C@H](O)[C@H]2O)cc1Cc1ccc(-c2ccc(F)cc2)s1</smiles><smiles>CCOc1ccc(Cc2cc([C@@H]3S[C@H](CO)[C@@H](O)[C@H](O)[C@H]3O)c(OC)cc2[N+](C)(C)CCCCCCOc2ccccc2)cc1</smiles><smiles>CCOc1ccc(Cc2cc([C@@]3(OC)O[C@](C)(CO)[C@@H](O)[C@H](O)[C@H]3O)ccc2Cl)cc1</smiles>

Figure 2. Phlorizin and its synthetic analgos: O-glycosides-Sergliflozin and T-1095; and C-glycosidic anti-diabetic drugs: Dapagliflozin, Empagliflozin, Canagliflozin, Ipagliflozin, Luseogliflozin, Tofoliflozin and Ertugliflozin 
and the drug lead development study, separated by almost a century of a dormant period. The contemporary research is interdisciplinary, cooperative (for the leading drug of the group - dapagliflozin, developed jointly by Astra Zeneca and Bristol-Myers Sqibb, ca. 20 clinical trials were already conducted) and far reaching in terms of hope for effective control of glycemia in large populations of patients. Moreover, it has great impact on basic science, for example inspiring research on new methods of chemical synthesis. Thus far, an addition of metalated aromatic synthons to temporarily protected gluconolactone, followed by the reductive removal of the hemiketal function, remains a method of choice for technical preparation of C-glycosyl analogs of aromatic O-glycosides [25]. However, many more experimental procedures suitable for a small laboratory scale exist, making new C-glycosides readily available category of NP analogs. It can be concluded, that considering favorable C-glycoside drug-like properties, they constitute privileged and also validated scaffolds for wide application in life sciences, including biochemical molecular probes, experimental drug candidates and molecular constructs for various new materials combining (comprising) in one molecule lipophilic and hydrophilic elements.

\section{References}

1. Alamgir ANM (2018) Therapeutic use of medicinal plants and their extracts Vol. 2 Phytochemistry and bioactive compounds. Springer AG, Cham, CH.

2. Rao V Ed. (2012) Phytochemicals - a global perspective of their role in nutrition and health. Intechopen.com, Rijeka, CRO.

3. Osbourn AE, Lanzotti V (2009) Plant-derived natural products; Synthesis, function, and application. Springer, Dordrecht, NL.

4. Buss AD, Butler MS Eds. (2010) Natural Product Chemistry for drug discovery. RSC Publishing, Cambridge, UK

5. Bon RS, Waldmann H (2010) Bioactivity-guided navigation of chemical space. Acc Chem Res 43: 1103-1114. [Crossref]

6. Lipinski CA, Lombardo F, Dominy BW, Feeney PJ (1997) Experimental and computational approaches to estimate solubility and permeability in drug discovery and development settings. Adv Drug Deliv Rev 23: 3-25. [Crossref]

7. Lipinski CA (2000) Drug-like properties and the causes of poor solubility and poor permeability. J Pharmacol Toxicol Methods 44: 235-249. [Crossref]

8. Firn RD, Jones CG (2003) Natural products--a simple model to explain chemical diversity. Nat Prod Rep 20: 382-391. [Crossref]

9. Kabera JN, Semana E, Mussa AR, He X (2014) Plant secondary metabolites: biosynthesis, classification, function and pharmacological properties. J Pharm Pharmacol 2: 377-392.

10. Solís D, Bovin NV, Davis AP, Jiménez-Barbero J, Romero A, et al. (2015) A guide into glycosciences: How chemistry, biochemistry and biology cooperate to crack the sugar code. Biochim Biophys Acta 1850: 186-235. [Crossref]
11. Veitch NC, Grayer RJ (2011) Flavonoids and their glycosides, including anthocyanins. Nat Prod Rep 28: 1626-1695. [Crossref]

12. Del Rio D, Rodriguez-Mateos A, Spencer JPE, Tognolini M, Borges G, et al. (2013) Dietary (poly)phenolics in human health: structures, bioavailability, and evidence of protective effects against chronic diseases. Antioxd Redox Signal 18: 1818-1892. [Crossref]

13. Xiao J (2017) Dietary flavonoid aglycones and their glycosides: which show better biological significance? Crit Rev Food Sci Nutr 57: 1874-1905. [Crossref]

14. Pereira DM, Valentao P, Pereira JA, Andrade PB (2009) Phenolics: from chemistry to biology. Molecules 14: 2202-2211.

15. Rodriguez-Mateos A, Vauzour D, Krueger CG, Shanmuganayagam D, Reed J, et al (2014) Bioavailability, bioactivity and impact on health of dietary flavonoids and related compounds: an update. Arch Toxicol 88: 1803-1853. [Crossref]

16. Chen L, Teng H, Xie Z, Cao H, Cheang WS, et al. (2018) Modification of dietary flavonoids towards improved bioactivity: an update on structure-activity relationship. Crit Rev Food Sci Nutr 58: 513-527. [Crossref]

17. Courts FL, Williamson G (2015) The Occurrence, Fate and Biological Activities of C-glycosyl Flavonoids in the Human Diet. Crit Rev Food Sci Nutr 55: 1352-1367. [Crossref]

18. Xiao J, Capanoglu E, Jassbi AR, Miron A (2016) Advance on the Flavonoid C-glycosides and Health Benefits. Crit Rev Food Sci Nutr 56 Suppl 1: S29-45. [Crossref]

19. Courts FL, Williamson G (2015) The Occurrence, Fate and Biological Activities of C-glycosyl Flavonoids in the Human Diet. Crit Rev Food Sci Nutr 55: 1352-1367. [Crossref]

20. Xiao J, Capanoglu E, Jassbi AR, Miron A (2016) Advance on the Flavonoid C-glycosides and Health Benefits. Crit Rev Food Sci Nutr 56 Suppl 1: S29-45. [Crossref]

21. Bokor E, Kun S, Goyard D, TÃ $\tilde{A}^{\text {th }}$ M, Praly J-P, Vidal S, Soms $\tilde{A}_{j k}$ L (2017) C-Glycopyranosyl Arenes and Hetarenes: Synthetic Methods and Bioactivity Focused on Antidiabetic Potential. Chem Rev 117: 1687-1764.

22. Yang Y, Yu B (2017) Recent Advances in the Chemical Synthesis of C-Glycosides. Chem Rev 117: 12281-12356. [Crossref]

23. Liu CF, Xiong DC, Ye XS (2014) "Ring opening-ring closure" strategy for the synthesis of aryl-C-glycosides. J Org Chem 79: 4676-4686. [Crossref]

24. Ehrenkranz JR, Lewis NG, Kahn CR, Roth J (2005) Phlorizin: a review. Diabetes Metab Res Rev 21: 31-38. [Crossref]

25. Zhang Y, Liu ZP (2016) Recent Developments of C-Aryl Glucoside SGLT2 Inhibitors. Curr Med Chem 23: 832-849. [Crossref]

26. Scheen AJ (2015) Pharmacodynamics, efficacy and safety of sodium-glucose co-transporter type 2 (SGLT2) inhibitors for the treatment of type 2 diabetes mellitus. Drugs 75: 33-59. [Crossref]

27. Ferrannini E (2017) Sodium-Glucose Co-transporters and Their Inhibition: Clinical Physiology. Cell Metab 26: 27-38. [Crossref]

28. d'Emden M, Amerena J, Deed G, Pollock C, Cooper ME (2018) SGLT2 inhibitors with cardiovascular benefits: transforming clinical care in type 2 diabetes mellitus. Diabetes Res Clin Pract 136: 23-31. [Crossref]

Copyright: (C2018 Grynkiewicz G. This is an open-access article distributed under the terms of the Creative Commons Attribution License, which permits unrestricted use, distribution, and reproduction in any medium, provided the original author and source are credited. 